\title{
PLAN OF STUDY FOR THE \\ NORTHERN ATLANTIC COASTAL PLAIN \\ REGIONAL AQUIFER SYSTEM ANALYSIS
}

U. S. Geological Survey

Water Resources Investigations 80-16

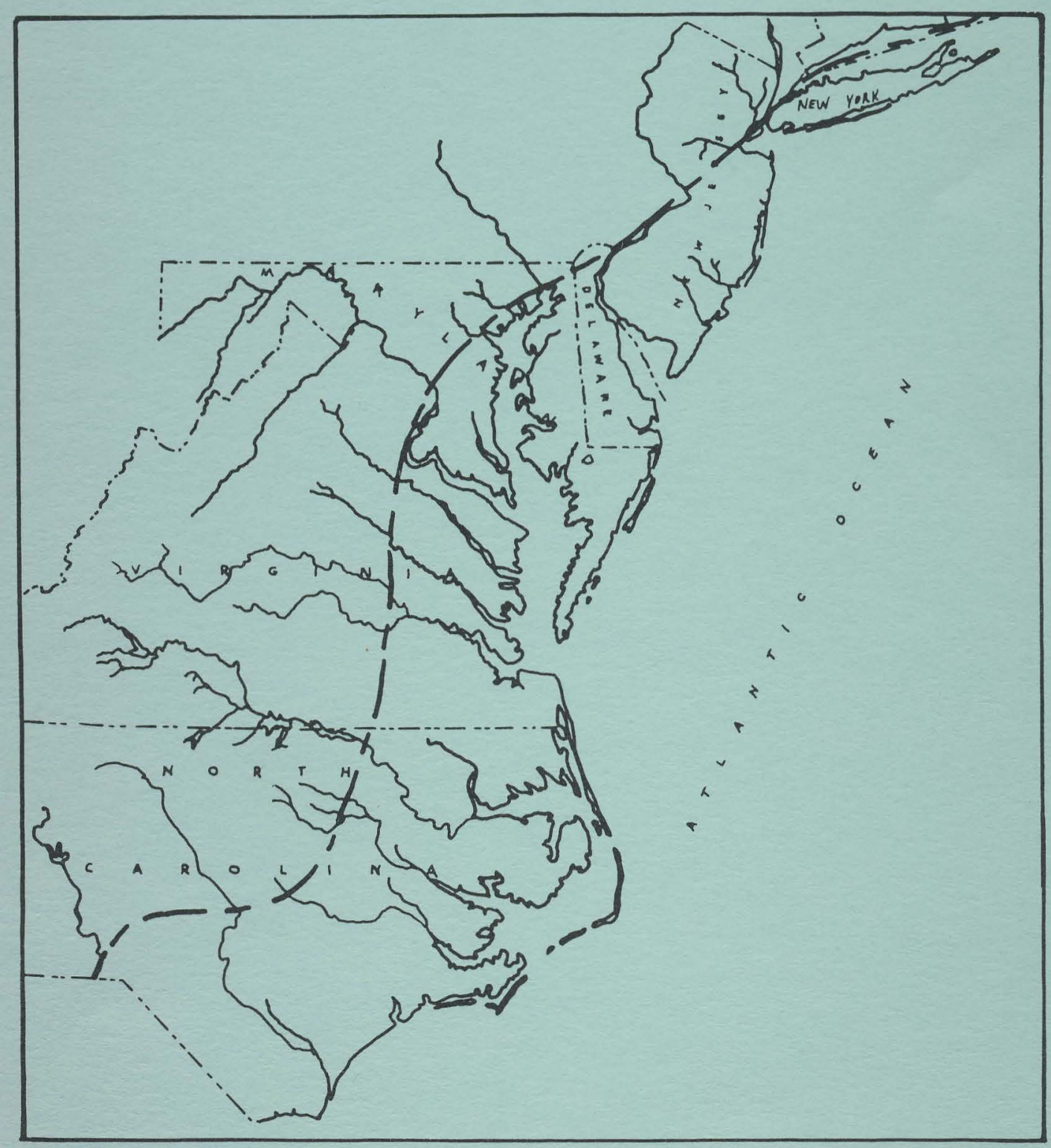




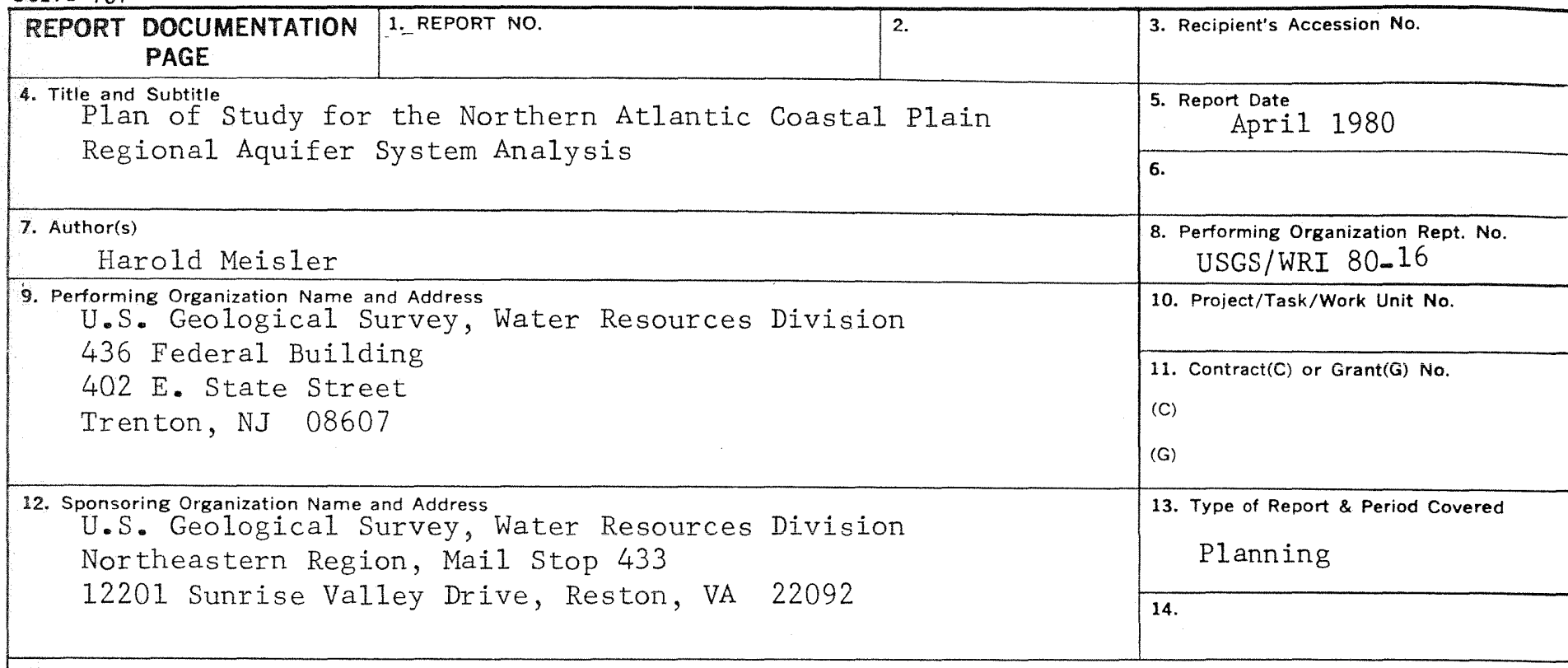

15. Supplementary Notes

16. Abstract (Limit: 200 words) Sediments of Cretaceous to Holocene age compose the Northern Atlantic Coastal Plain aquifer system in an area of 50,000 square miles from North Carolina to New York. The aquifer system is the principal source of water supply for most of the area. About 1.4 billion gallons are withdrawn each day. Increasing pumpage has createf problems such as declining water levels, saltwater intrusion, and land subsidence. The U.S. Geological Survey has begun a comprehensive study of the aquifer system that will define the geology, hydrology, and geochemistry of the system. The effects of future utilization of the aquifer system will be determined and alternative water withdrawal plans will be evaluated through computer simulation modeling. This report describes the objectives, organization, and work plans of the study.

17. Document Analysis a. Descriptors

*Aquifers, *Atlantic Coastal Plain, *Computer mode1s, Delaware, Geochemistry, *Groundwater, Maryland, New Jersey, New York, North Carolina, Pumping, *Regional analysis Saline water-freshwater interface, *Project planning, Water chemistry, Water management, Virginia.

b. Identifiers/Open-Ended Terms

Cones of depression, Delmarva peninsula, Ground-water management, Hydrogeologic maps, Long Island, Regional aquifer system.

c. COSATI Field/Group

\begin{tabular}{|l|l|l|l|}
\hline $\begin{array}{l}\text { 18. Availability Statement } \\
\text { No restriction on distribution }\end{array}$ & $\begin{array}{l}\text { 19. Security Class (This Report) } \\
\text { UNCLASSIFIED }\end{array}$ & $\begin{array}{l}\text { 21. No. of Pages } \\
\text { 20. Security Class (This Page) } \\
\text { UNCLASSIFIED }\end{array}$ & $\begin{array}{l}\text { 22. Price } \\
\text { (See ANSi-Z39.18) }\end{array}$ \\
\hline
\end{tabular}


PIAN OF STUDY FOR THE NORTHERN ATLANTIC COASTAL PLAIN REGIONAL AQUIFER SYSTEM ANALYSIS

By Harold Meisler

U.S. GEOLOGICAI SURVEY

Water Resources Investigations 80-16

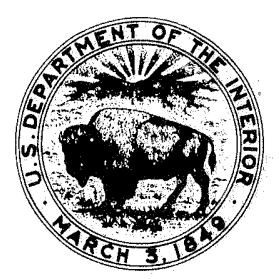

April 1980 


\author{
UNITED STATES DEPARTMENT OF THE INTERIOR \\ Cecil D. Andrus, Secretary \\ GEOLOGICAL SURVEY \\ H. W. Menard, Director
}

For additional information write to:

U.S. Geological Survey

436 Federal Building

P.0. Box 1238

Trenton, New Jersey 08607 


\section{CONTENTS}

Abstract-n_-

Introduction-

Hydrogeologic setting---

Problem-_-

Objectives-

Approach-_-

Organization of the study-_- 11

Relation to other studies-_.

Plan of study-----

District work plans-_-

Maryland, Delaware, and the District of Columbia----- 18

New Jersey-_-_-_-_-_-_-_-_-_-_-_-_-_-_-_-_- 21

New York_- 23

North Carolina-_-_-_._- 24

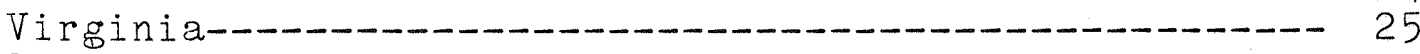

Selected references-_-__ 27

\section{ILLUSTRATIONS}

Figure 1. Map showing the location of northern Atlantic Coastal Plain-_-_-_-_._-

2. Configuration of the bedrock surface beneath

the Coastal Plain sediments-_-_-_- 4

3. Structure contour map of the top of the

Cretaceous sediments_- 6

4. Stratigraphic correlation chart of the northern Atlantic Coastal Plain----

5. Schedule of work elements_.............. 17

6. Preliminary designation of aquifers for district work plans-_- 19

TABLES

Table 1. Estimated ground-water withdrawal in 1978---- 8 
PLAN OF STUDY FOR THE NORTHERN ATLANTIC COASTAL

PLAIN REGIONAL AQUIFER SYSTEM ANALYSIS

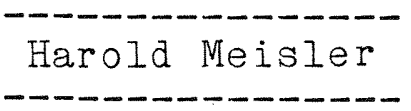

\section{ABSTRACT}

Sediments of Cretaceous to Holocene age compose the Northern Atlantic Coastal Plain aquifer system in an area of 50,000 square miles in parts of New York, New Jersey, Delaware, Maryland, Virginia, and North Carolina. The aquifer system is a major source of water supply in the area. About 1.4 billion gallons is withdrawn from its aquifers each day. Increasing withdrawal of ground water has created or intensified several problems such as declining water levels, development of large cones of depression, saltwater intrusion, spreading of ground-water contamination, and land subsidence.

The U.S. Geological Survey has begun a comprehensive study that will define the geology, hydrology, and geochemistry of the aquifer system. The effects of future utilization of the aquifer system will be determined and alternative plans for water withdrawal will be evaluated through computer simulation modeling. This report describes the objectives, organization, and work plans of the study, and describes the work to be accomplished in each U.S. Geological Survey District of the study area. 


\section{INTRODUCTION}

The Northern Atlantic Coastal Plain is an area of about 50,000 square miles extending northeastward from North Carolina to Long Island, New York (figure 1). It is underlain by an eastward thickening wedge of predominantly unconsolidated sediments. This sedimentary wedge forms a complex aquifer system that provides most of the area's water supply. Withdrawal of water from the system is estimated to have been 1.4 billion gallons per day in 1978. Problems associated with increasing withdrawal will adversely affect the long-term utilization of the aquifer system.

\section{Hydrogeologic Setting}

Northern Atlantic Coastal Plain sediments consist mostly of sand, silt, clay, shale, and limestone with minor amounts of gravel. Most of the limestone occurs in North Carolina, although minor amounts are present as far north as New Jersey. The Coastal Plain sediments range in age from Early Cretaceous (probably Jurassic age locally) to Holocene and overlie crystalline bedrock of Paleozoic and Precambrian (?) age and sedimentary and igneous rocks of Triassic age. Generally, the sediments dip gently to the east or southeast at 10 to 50 feet per mile, thickening from a featheredge at the western limit of the Coastal Plain to about 8,000 feet at the eastern edge of the Delmarva Peninsula and 10,000 feet at Cape Hatteras, North Carolina. Figure 2 shows the configuration of the top of the bedrock beneath the Coastal Plain sediments. 


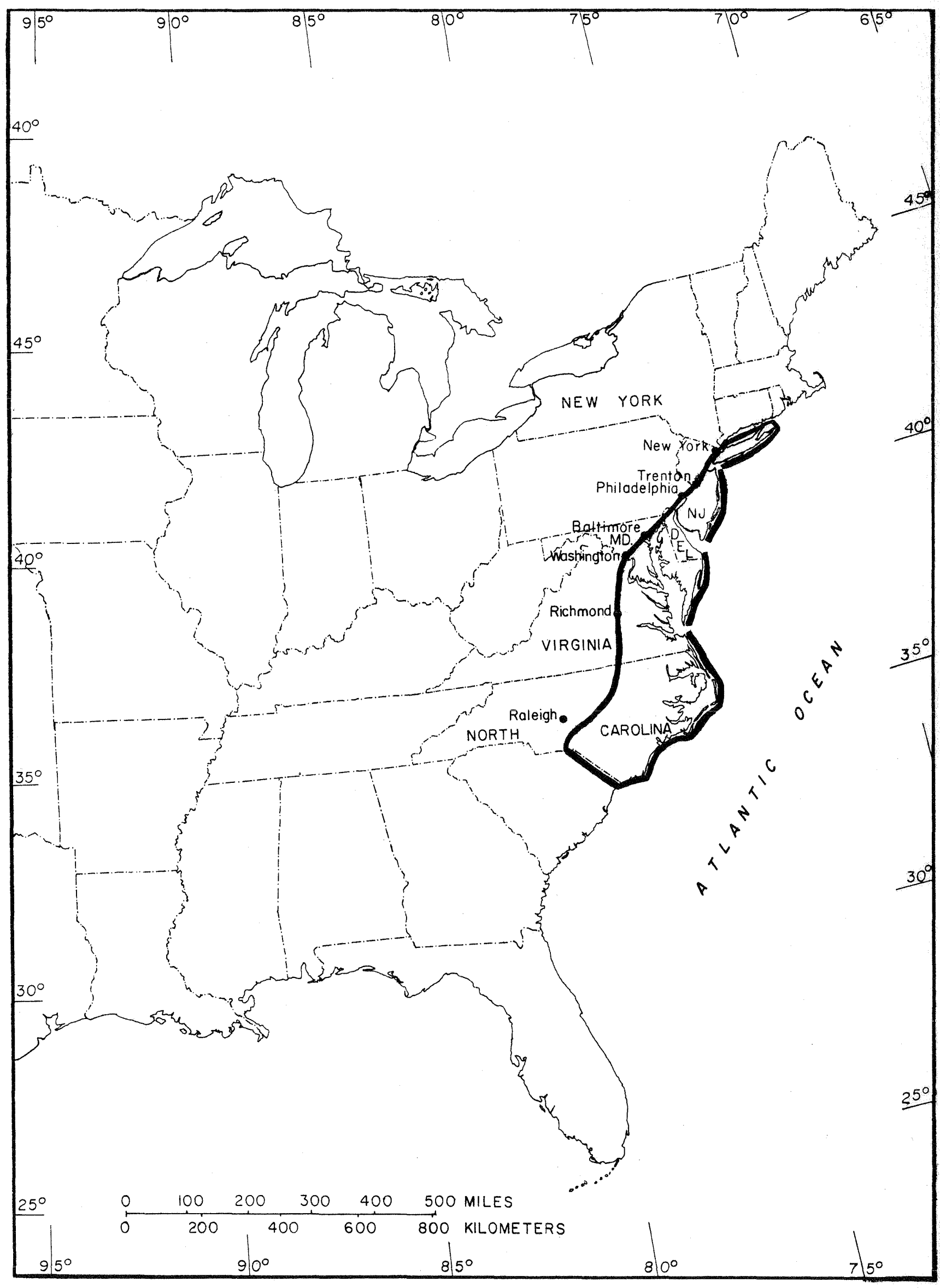

Figure 1...Location of the Northern Atlantic Coastal Plain. 


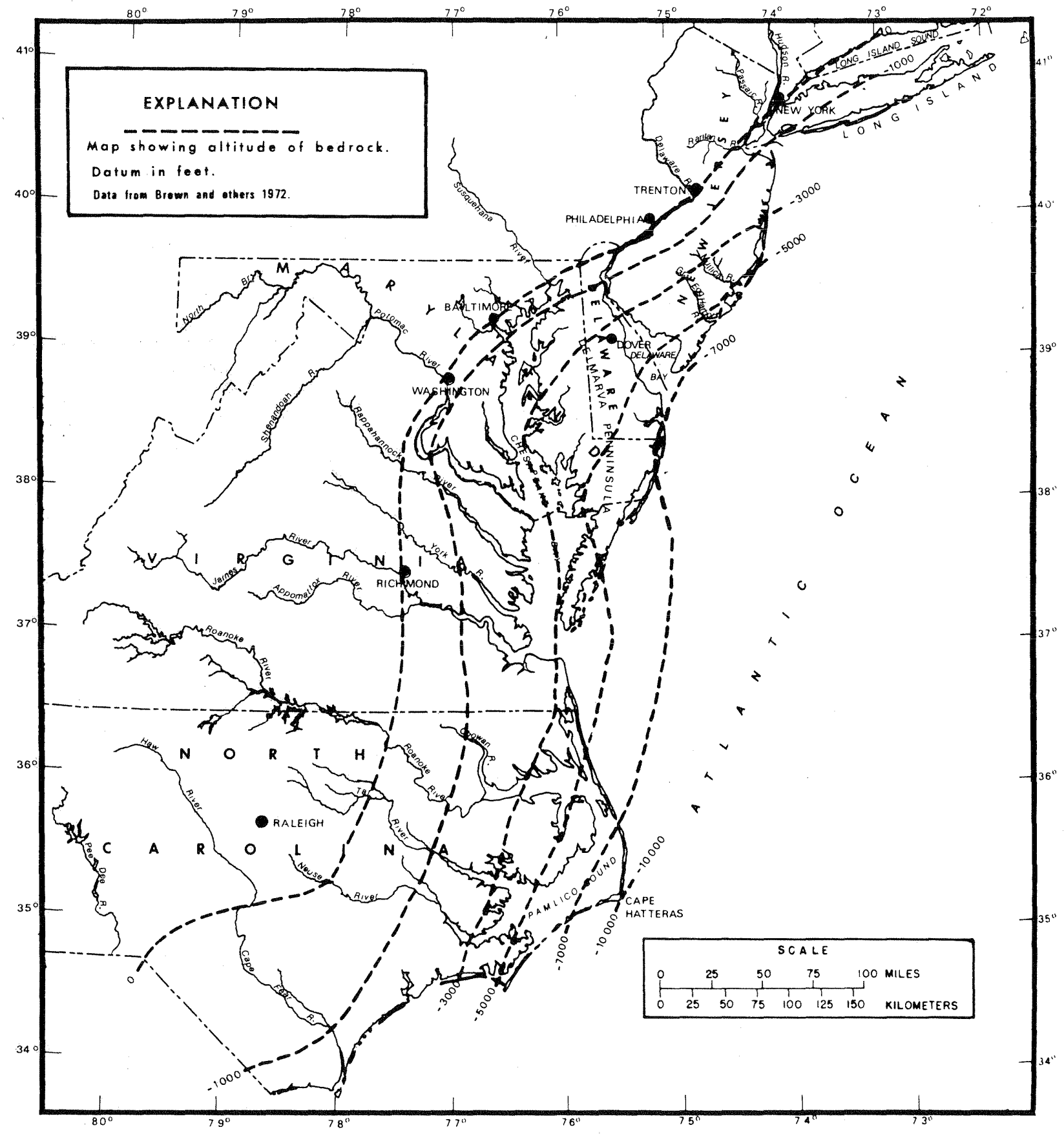

Figure 2... Configuration of the bedrock surfaces beneath the Coastal Plain sediments. 
Sediments of Cretaceous age thicken eastward from a featheredge along their western boundary to about 5,000 feet at the southern tip of New Jersey and the eastern edge of the Delmarva peninsula and to 5,900 feet as reported by Perry and others (1975, p. 1534) at Cape Hatteras, North Carolina. Cretaceous sediments constitute about three quarters of the total sedimentary wedge and Lower Cretaceous sediments make up about half of the wedge. The configuration of the top of the Cretaceous sediments is shown in figure 3. Lower Cretaceous sediments are largely of nonmarine origin except in North Carolina where sediments of marine origin predominate. Upper Cretaceous deposits contain marine, marginal marine, and nonmarine sediments. Nonmarine sediments are most abundant in the lower units of the Upper Cretaceous except in North Carolina and New Jersey. where marine and marginal marine sediments are prominent. Marine and marginal marine sediments predominate in the upper units of the Upper Cretaceous.

The overlying sediments of Cenozoic age thicken eastward to about 2,000 feet at the southern tip of New Jersey and the eastern edge of the Delmarva Peninsula and to about 2,800 feet at Cape Hatteras, North Carolina. Cenozoic sediments constitute about one quarter of the Coastal Plain sedimentary wedge. Sediments of Paleocene through Miocene age are chiefly of marine and marginal marine origin, whereas sediments of Pliocene through Holocene age are largely nonmarine but contain some marginal marine deposits. Correlation of stratigraphic units in the various states of the Northern Atlantic Coastal Plain is shown in the Correlation Chart (figure 4). Also shown on the chart is the stratigraphic sequence of seventeen chronostratigraphic units (strata of the same age that have the same or different Iithologies) developed by Brown, Miller, and Swain (1972) for the entire Northern Atlantic Coastal Plain. The chronostratigraphic units are correlated by system and series with the other stratigraphic sequences but correlation of individual chronostratigraphic units with individual formations is not implied in the Correlation Chart.

Many of the more permeable stratigraphic units have been identified as aquifers. These are listed for each of the Northern Coastal Plain states in the section entitled "District Work Plans" and their stratigraphic relation shown in figure 6. The aquifers are separated by confining beds of widely differing permeability, ranging from very leaky confining layers, such as the silts of Miocene age on the Delmarva Peninsula, to almost impermeable layers, such as clays of Cretaceous age in Maryland and New Jersey. In general, however, the aquifers are not independent units and each is part of a complex hydrologic system. Sand aquifers of Cretaceous age supply about two-thirds of the present-day water supply as indicated.by table 1 which shows estimates of ground-water withdrawal by locality and geologic age. 


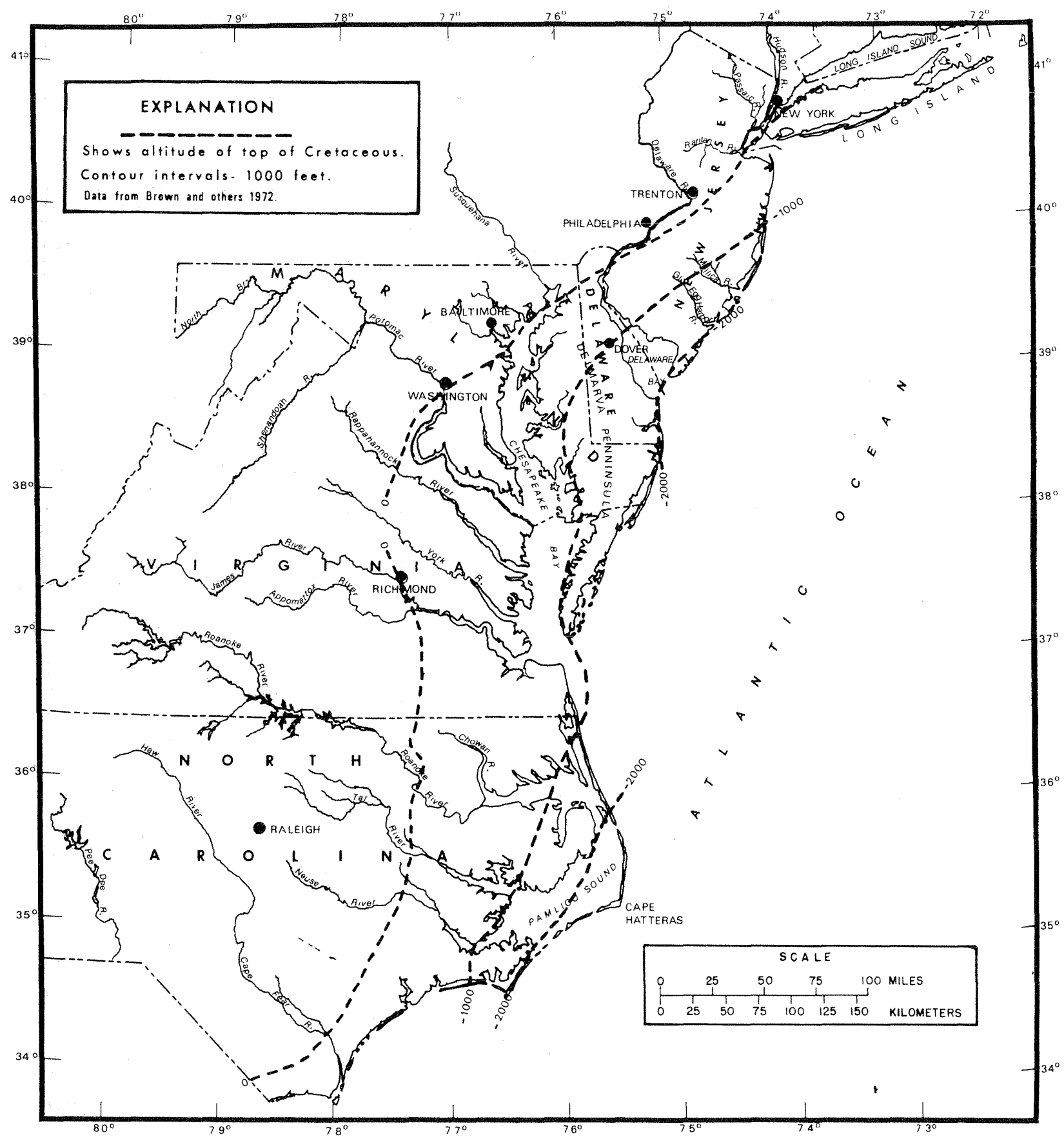

Figure 3... Structure contour map of the Cretaceous sediments. 
Figure 4.--Generalized stratigraphic correlation chart of the Northern Atlantic Coastal Plain

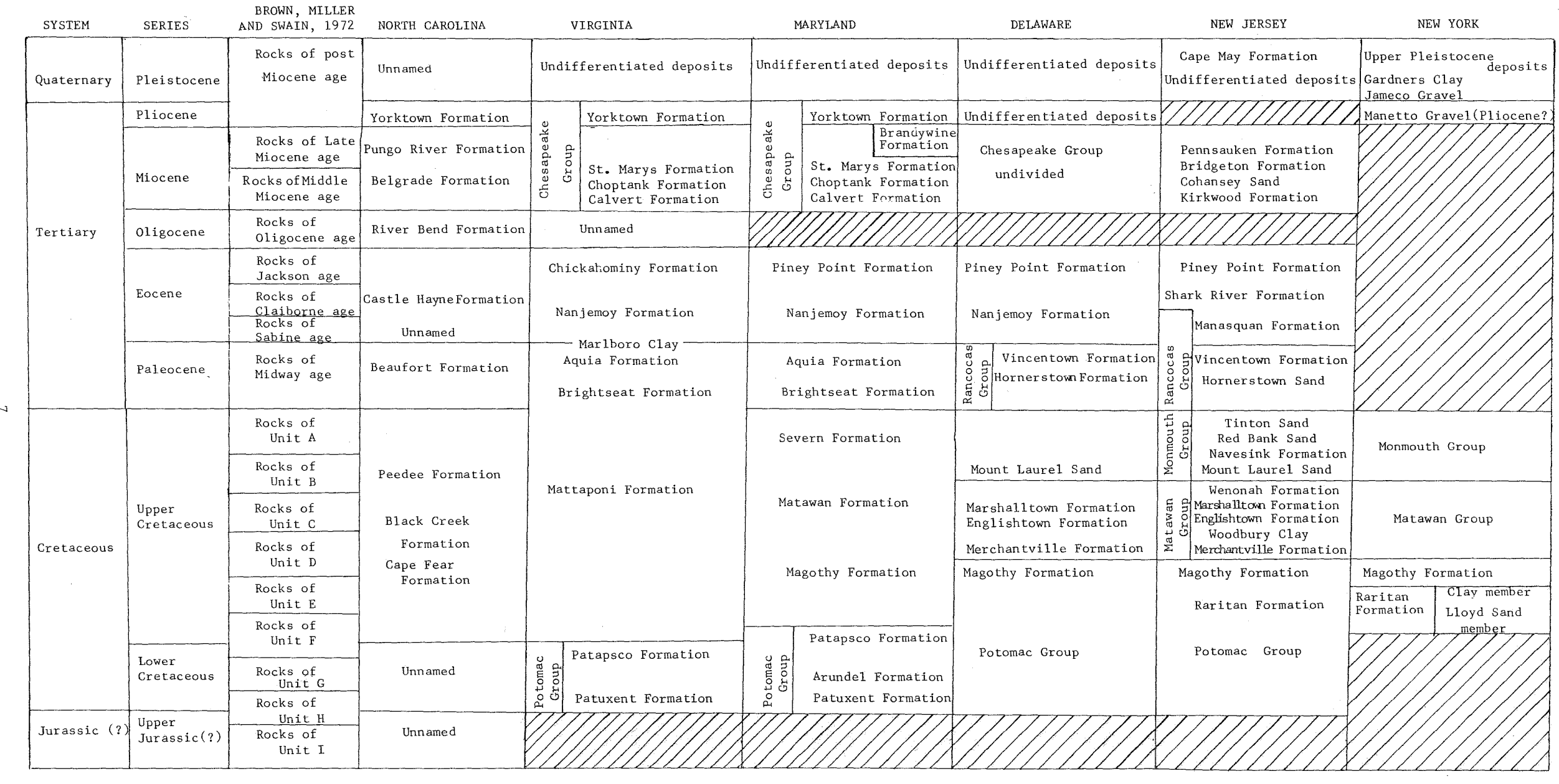

NoTE: Chronostratigraphic units of Brown, Miller, and Swain, 1972, are not correlated here with other formations or groups. Not all formations appearing on the same horizontal line are necessarily exact time equivalents. The diagonal lines indicate that the section is not present. 
Table 1.--Estimated ground-water withdrawals (million gallons per day)

$$
1978
$$

ESTIMATED WITHDRAWALS FROM AQUIFERS,

LOCALITY and
BY AGE

Tertiary Quaternary

Long Island, N.Y.

New Jersey

Maryland, Delaware

District of Columbia

Virginia

North Carolina

Total, by age
Cretaceous

375

265

90

140

60

930
125

120

50

15

95

270
500

400

200

145

155

TOTAL

500
400
200
145
155
400


$\underline{\text { Problem }}$

The long-term utility of the Northern Atlantic Coastal Plain aquifer system is threatened by increasing demand for water supply. This aquifer system is a major source of water supply for urban and suburban centers and industries, as well as for irrigation and domestic use. Intensive ground-water withdrawal has resulted in declining water levels and development of large cones of depression in several aquifers while other aquifers having significant development potential remain relatively unused. Major cones of depression resulting from large ground-water withdrawals for industrial and public supply occur in New Jersey, the Delmarva Peninsula, and southeastern Virignia. Ground-water pumpage associated with phosphate mining in northeastern North Carolina has created a cone of depression extending over an area of more than 2,000 square miles. Water levels have declined more than 125 feet at the center of the North Carolina cone. Water levels have declined 200 feet at the center of the cone at Franklin, Virginia. This cone extends over an area of more than 5,000 square miles in Virginia and North Carolina. Coalescing cones of depression underlie virtually the entire 4,000 square mile Coastal Plain of New Jersey and 3,000 square miles of northern Delmarva Peninsula. Water-level declines are typically 100 to 200 feet at the center of the cones in New Jersey and on the Delmarva Peninsula.

Declining water levels, in turn, are causing saltwater intrusion and movement of contaminants towards pumping centers. Saltwater intrusion is possible from two sources: saline water in the ocean, bays, and estuaries overlying or adjacent to the shallow parts of the aquifers; and saline ground water in the deeper parts of the aquifers. The potential for saltwater intrusion appears greatest in Long Island, southeastern Virginia, northeastern North Carolina, and New Jersey. The complexity of saltwater-freshwater relations in the coastal Plain aquifers is underscored by the occurrence "of relatively fresh water (salinities less than 3 parts per thousand) extending as much as 60 nautical miles seaward from the New Jersey coast." (Hathaway and others, 1976, p. 4).

Release of water from storage in confining layers has caused an unknown amount of consolidation of some of these layers resulting in subsidence of the land surface. Indications of land subsidence are greatest in New Jersey and in southeastern Virginia where subsidence is estimated to be as high as 0.2 inch per year. 
Quantitative evaluation of this large, complex, and inadequately understood aquifer system and the tools to predict the consequences of its continued use are needed in order to develop the system safely and efficiently. A regional study, encompassing the entire Northern Atlantic Coastal Plain is needed for a comprehensive understanding of the aquifer system and its response to multistate development.

\section{Objectives}

The objectives of the Northern Atlantic Coastal Plain Regional aquifer system analysis are:

1. Define the regional aquifer system. Describe its geology, hydrology, and geochemistry. Define the predevelopment flow system and the changes caused by development.

2. Simulate both the predevelopment and present flow conditions in the aquifer system by digital computer models.

3. Use simulation models to determine the effects of continued and future stress on the regional aquifer system and on streamflow. Evaluate alternative ground-water withdrawal plans by estimating their hydrologic effects.

4. Determine the location of the saltwater-freshwater interface and evaluate its movement.

5. Formulate a regional data-collection program to monitor future water use, water levels, and water-quality changes and to provide information needed for more detailed predictive models.

\section{Approach}

The objectives of the study will be met through the following steps: (1) compiling and analyzing available geologic, hydrologic, and water quality data; (2) developing regional hydrogeologic and geochemical maps; (3) collecting and analyzing additional data in order to improve and refine regional maps; (4) developing and calibrating regional steady state and transient computer simulation models; (5) studying the relationship of saltwater to freshwater and (6) using simulation models to evaluate the effects of ground-water withdrawals on ground-water movement, water levels, and base flow of streams. 
Regional computer models will simulate from eight to ten aquifers. Aquifers and confining beds will be subdivided into an appropriate number of model layers to be determined during the study. From 2,000 to 4,000 nodes will be utilized for each model layer, an average size node covering 40 to 60 square miles. They will cover the entire Northern Atlantic Coastal Plain and part of the adjacent continental shelf. Subregional computer models will be developed within U.S. Geological Survey Districts. Each subregional model will cover approximately the coastal plain area of one or, in the case of Maryland and Delaware, two states. The Virginia District model will extend southward to Albemarle sound in North Carolina and the North Carolina District model will extend southward from Albemarle Sound to South Carolina. Subregional models will simulate up to ten layers and have on the order of 2,000 to 4,000 nodes per layer. Variable grids containing fine grid spacing will be utilized in areas of heaviest pumping or other significant problems.

\section{Organization of the Study}

The Northern Atlantic Coastal Plain regional aquifer system analysis will be done during october 1, 1979 to September 30, 1984. A regional project staff of the U.S. Geological Survey will be located in Trenton, New Jersey. Subregional projects will be conducted concurrently for four years, October 1, 1979 to September 30, 1983, in five U.S. Geological Survey Districts: New York (Syosset, N.Y.), New Jersey (Trenton, N.J.), Maryland, Delaware and the District of Columbia (Towson, Md.), Virginia (Richmond, Va.), and North Carolina (Raleigh, N.C.). Subregional projects will be funded as part of the regional aquifer system analysis.

The regional project staff will design and conduct the regional study in coordination with each participating U.S. Geological Survey District and will provide technical direction for the planning and execution of the subregional projects. The regional staff will coordinate regional and subregional projects, develop regional steady state and transient computer simulation models, and supply boundary conditions for the subregional computer simulation models.

Subregional projects will be the responsibility of the respective Districts. District staffs will develop subregional steady state and transient computer simulation models as described in this report in the section entitled "District Work Plans." The District staffs will collect and analyze the data required for subregional and regional models. The subregional projects will also furnish much of this information to the regional project staff in the form of hydrogeologic and geochemical maps. 
Relation to Other Studies

Most of the knowledge of the ground-water resources and hydrogeology of the Northern Atlantic Coastal Plain has resulted from the long-term cooperative program of the U.S. Geological Survey with state and other governmental agencies. Principal cooperating agencies have been the Delaware Geological Survey, Maryland Geological Survey, New Jersey Department of Environmental Protection (formerly Department of Conservation and Economic Development), North Carolina Department of Natural Resources and Community Development (formerly Department of Water and Air Resources), Virginia State Water Control Board, Nassau County (New York) Department of Public. Works, Suffolk County (New York) Water Authority, and Suffolk County Department of Health Services.

The Northern Coastal Plain regional aquifer study will be coordinated with related cooperative projects in the participating Districts. These include, in addition to ongoing programs to collect hydrologic data in each District:

(a) Countywide ground-water studies in Nassau and Suffolk Counties, New York, James City and Fairfax Counties, Virginia;

(b) Computer simulation models in Nassau and Suffolk Counties, New York, several models of the Potomac Group in Delaware and Maryland, a model of the Piney Point and Cheswold aquifers in Delaware, a model of the Aquia, Piney Point, and Nanjemoy aquifers in southern Maryland, and a model of the Cohansey Sand in New Jersey;

(c) Other projects such as subsidence studies in New Jersey and southeastern Virginia, hydrogeology of the water-table aquifer in the Delmarva peninsula, hydrology of the Dismal Swamp, Virginia, hydrology and water quality of the Potomac-Raritan-Magothy aquifer system in the Delaware Valley, New Jersey, saltwater-freshwater relations in Virginia, and the feasibility of recharging tertiary treated sewage in Nassau County, New York.

Unpublished data collected for the regional aquifer study as well as simulation models and their documentation will be released and available to cooperating agencies and the public. 


\section{PLAN OF STUDY}

Work elements of the study are shown in the following outline.

A. Planning and staffing.

I. Develop regional and subregional project proposals and descriptions.

2. Develop detailed work plans for regional and subregional projects.

3. Assemble staffs in regional and district offices. The regional staff will consist of four hydrologists with the following principal areas of responsibility; (a) overall direction of project, (b) hydrology and geology, (c) computer simulation, and (d) geochemistry.

4. Organize regional liaison committee.

B. Hydrogeology.

1. Compile and review available data on the hydrogeologic framework.

a. Correlate stratigraphic data.

b. Identify the aquifers and confining layers; their distrioution, structure, and thickness.

c. Evaluate the following hydraulic properties of aquifers and confining layers: hydraulic conductivity, storage coefficient, specific storage, specific yield.

2. Evaluate and interpret data.

Interpret hydrogeologic maps and other information needed for regional and subregional computer simulation modeling.

3. Data collection program.

a. Conduct test drilling, pumping tests, and geophysical logging.

b. Update stratigraphic and structural data.

c. Update information on the hydraulic properties of aquifers and confining layers.

d. Collect subsidence data in Virginia and New Jersey. 
4. Revise hydrogeologic maps and information needed for improved regional and subregional computer simulation modeling.

5. Complete interpretation of hydraulic properties based on computer simulation modeling.

C. Hydrology.

1. Compile and review available hydrologic data.

a. Water-level histories, potentiometric heads.

b. Predevelopment recharge and discharge.

c. Pumpage from wells.

d. Ground water-surface water relations.

2. Evaluate and interpret data.

Interpret hydrologic maps, hydrographs, and other information needed for regional and subregional computer simulation modeling.

3. Data collection program. data.

a. Update and improve pumpage and potentiometric head

b. Update and improve base-flow data.

4. Revise hydrologic maps and information needed for improved regional and subregional computer simulation modeling.

5. Prepare final interpretation of flow system based on computer simulation modeling.

D. Geochemistry and water quality.

1. Assemble and evaluate available data.

a. Develop preliminary maps showing concentrations of significant constituents.

b. Determine significant historical changes in water quality.

2. Develop program of water-quality sampling and analysis.

3. Revise preliminary maps and develop new water-quality 
maps .

4. Relate distribution of water-quality parameters to the three-dimensional flow system. Relate water quality to recharge areas, movement within aquifers and confining layers.

5. Study the occurrence of saltwater, define saltwater-freshwater relations, and evaluate saltwater movement as a result of ground-water withdrawal and past changes in sea level.

6. Develop appropriate ground-water quality models.

E. Computer simulation models of the aquifer system.

1. Develop steady-state multilayer regional model.

a. Develop a digital computer modeling program.

b. Determine model boundaries, the aquifers to be simulated, the number of model layers to be used, and the finite difference grid.

c. Calibrate model with predevelopment water levels.

d. Provide boundary conditions to subregional models and help guide development of subregional steady-state models.

e. Apply sensitivity analysis to determine the most important hydrologic properties and to determine new data needs.

f. Revise and improve the model using new data.

2. Develop transient multilayer regional model. Development of the transient model will be based upon results of the steady-state model. Calibration of the transient model will be based on historical water levels, and pumpage data.

3. Develop other simulation models.

a. Cross-sectional models.

b. Saltwater-freshwater models.

c. Ground-water quality models. 
F. Utilization of simulation models.

1. Develop several scenarios of projected ground-water withdrawal.

2. Test scenarios using simulation models to determine hydrologic effects.

G. Reports.

1. Plan of study (WRI).

2. Regional hydrogeology (WRI, professional paper chapter).

3. Regional geochemistry (WRI, professional paper chapter).

4. Computer simulation models (professional paper chapters).

5. Model documentation (open file).

6. Saltwater-freshwater relationships (journal article, professional paper chapter).

7. Other special studies (journal articles).

H. Future studies and data collection.

1. Identify data collection programs needed to improve understanding of the aquifer system and update computer simulation models and their predictive capabilities.

2. Identify areas for more detailed computer simulation models.

Scheduling of these work elements is given in figure 5 . 


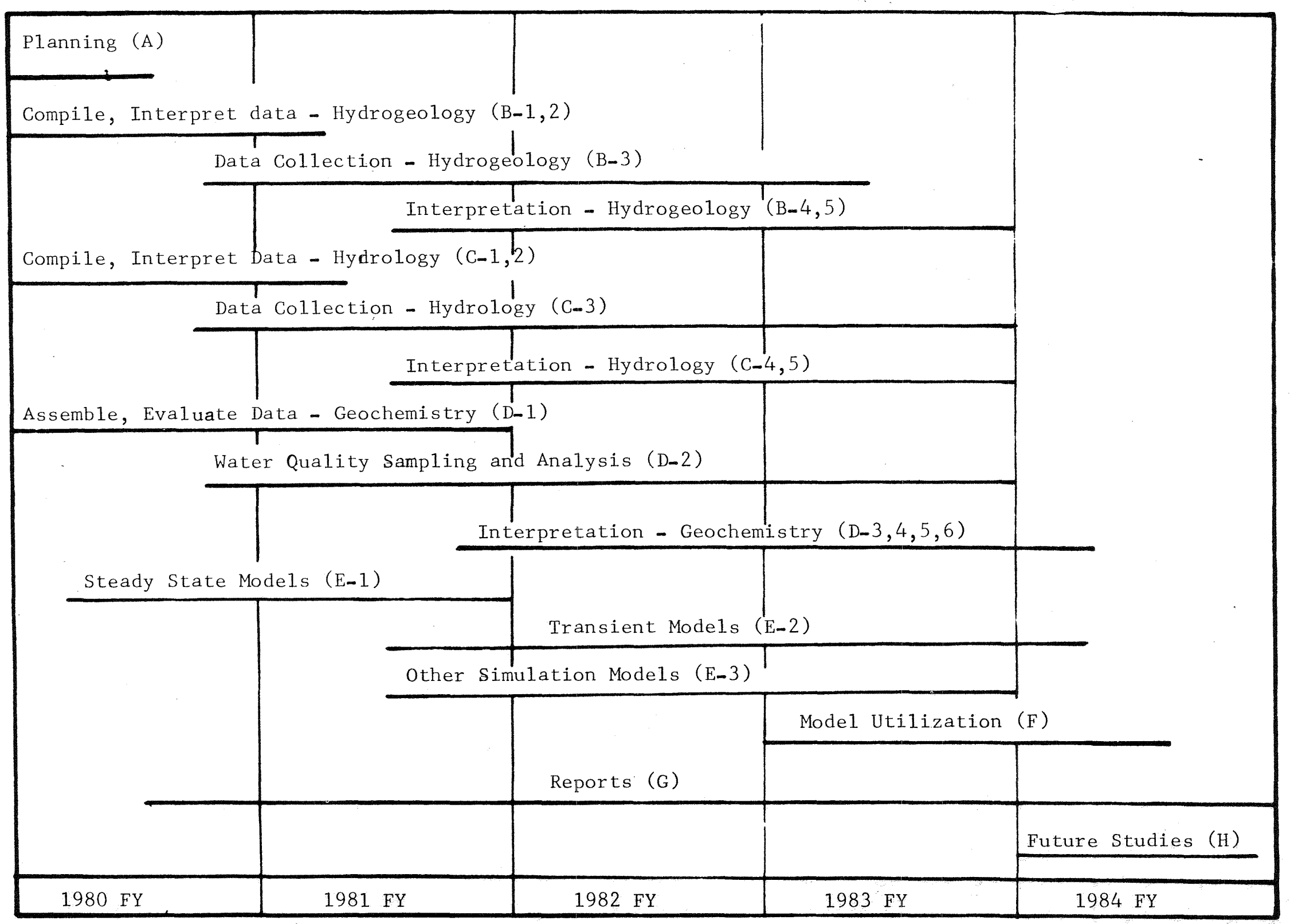

Figure 5.--Schedule of work elements. Letters in parentheses refer to outline headings in the text. 
Maryland, Delaware, and The District of Columbia

The Coastal Plain aquifer system underlies about 8,000 square miles in Maryland, Delaware, and the District of Columbia. The Coastal Plain sediments dip southeasterly and thicken to about 8,000 feet in the vicinity of Ocean City, Maryland. Eight principal and several minor aquifers have been identified in the area. From youngest to oldest, the principal aquifers (see figure 6) are: the Unconfined aquifer which includes beds of Pleistocene and Pliocene age; the upper Chesapeake aquifer of Miocene and Pliocene age; lower Chesapeake aquifer of Miocene age; the Piney Point aquifer of Eocene age; Aquia and Rancocas aquifers of Paleocene age; the Magothy aquifer of Late Cretaceous age; and the Patapsco and Patuxent (Potomac Group) aquifers of Early and Late Cretaceous age.

Withdrawal from these units is estimated at $200 \mathrm{Mgal} / \mathrm{d}$. A total of about $90 \mathrm{Mgal} / \mathrm{d}$ was withdrawn from the three aquifers of Cretaceous age, $50 \mathrm{Mgal} / \mathrm{d}$ from the four aquifers of Tertiary age, and $60 \mathrm{Mgal} / \mathrm{d}$ is withdrawn from the unconfined aquifer.

Large cones of depression have developed in more than a dozen areas in Maryland and Delaware as a result of ground-water withdrawal. Some of the more significant of these are in (1) the Potomac Group in the Baltimore industrial area, (2) the Aquia and Piney Point aquifers in the Calvert Cliffs-Lexington Park area in southern Maryland, (3) the Magothy and Piney Point aquifers in the vicinity of Cambridge on the eastern shore of Maryland, and (4) the Piney Point aquifer in the vicinity of Dover, Delaware.

Problems or potential problems requiring investigation include intrusion of saline water from Chesapeake and Delaware Bays as well as from the ocean and land subsidence from dewatering and consequent compaction of confining beds. 

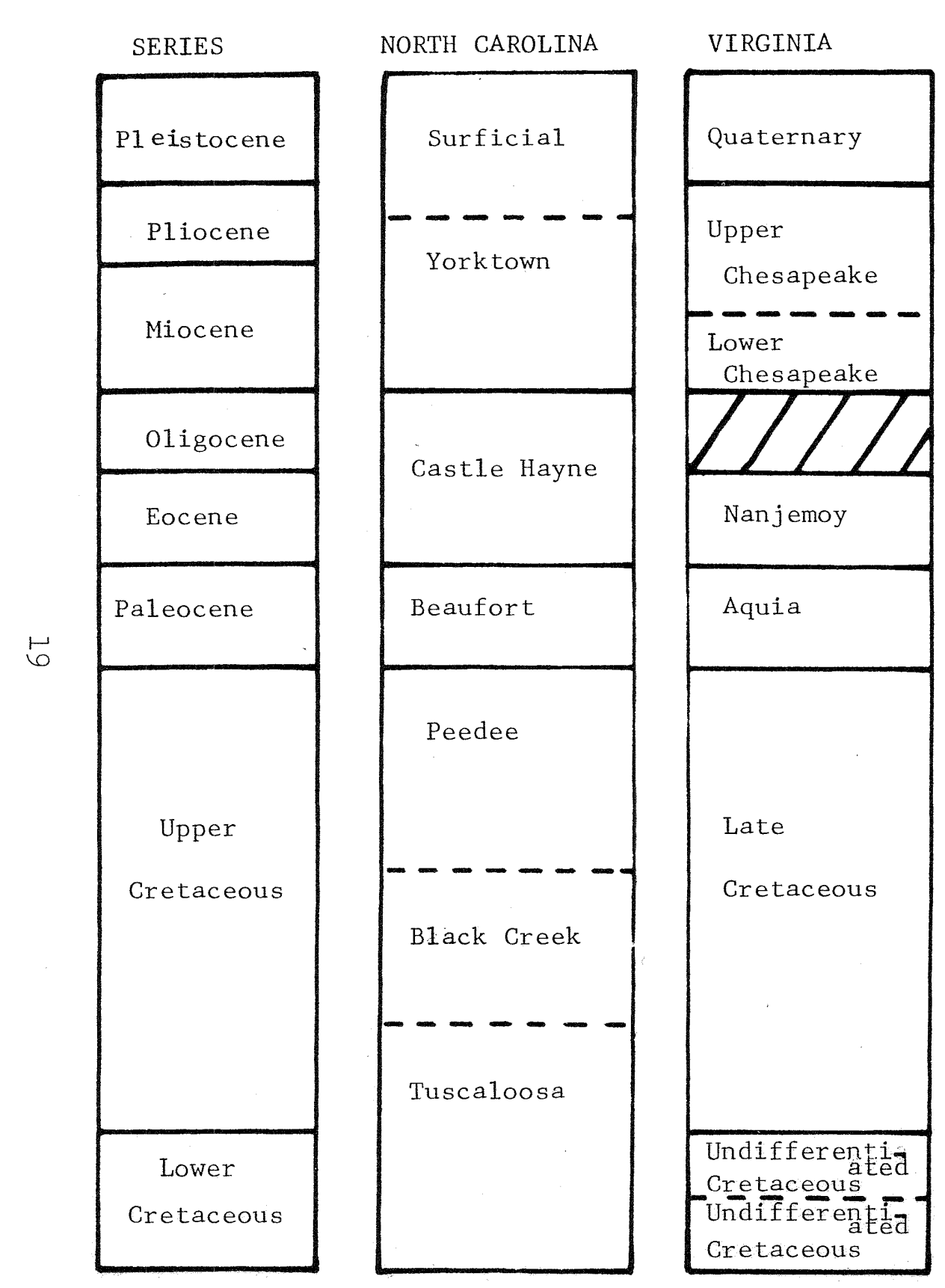

MARYLAND, DELAWARE

DISTRICT OF COLUMBIA

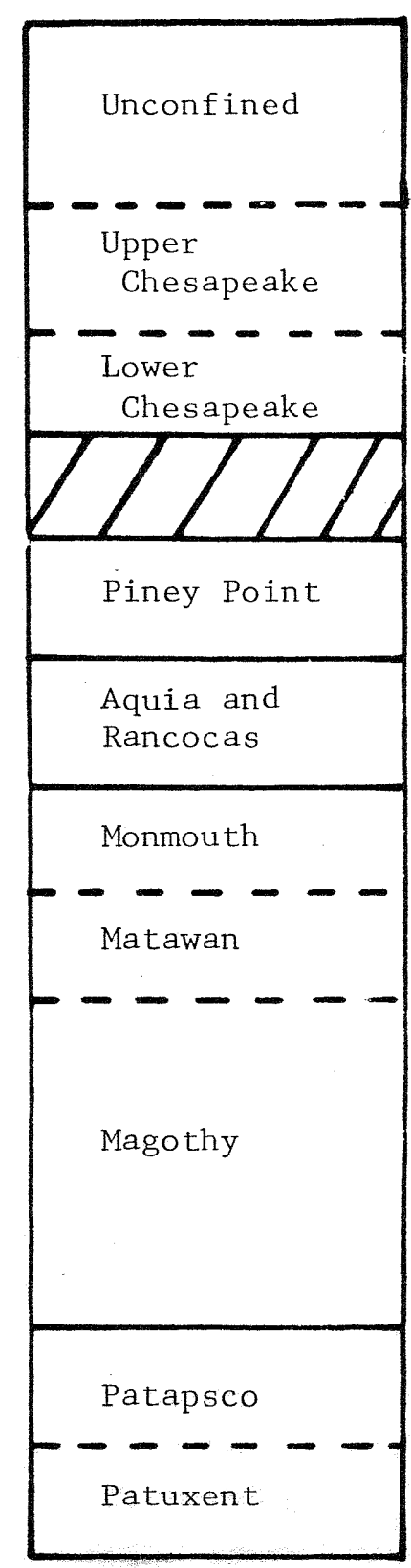

NEW JERSEY

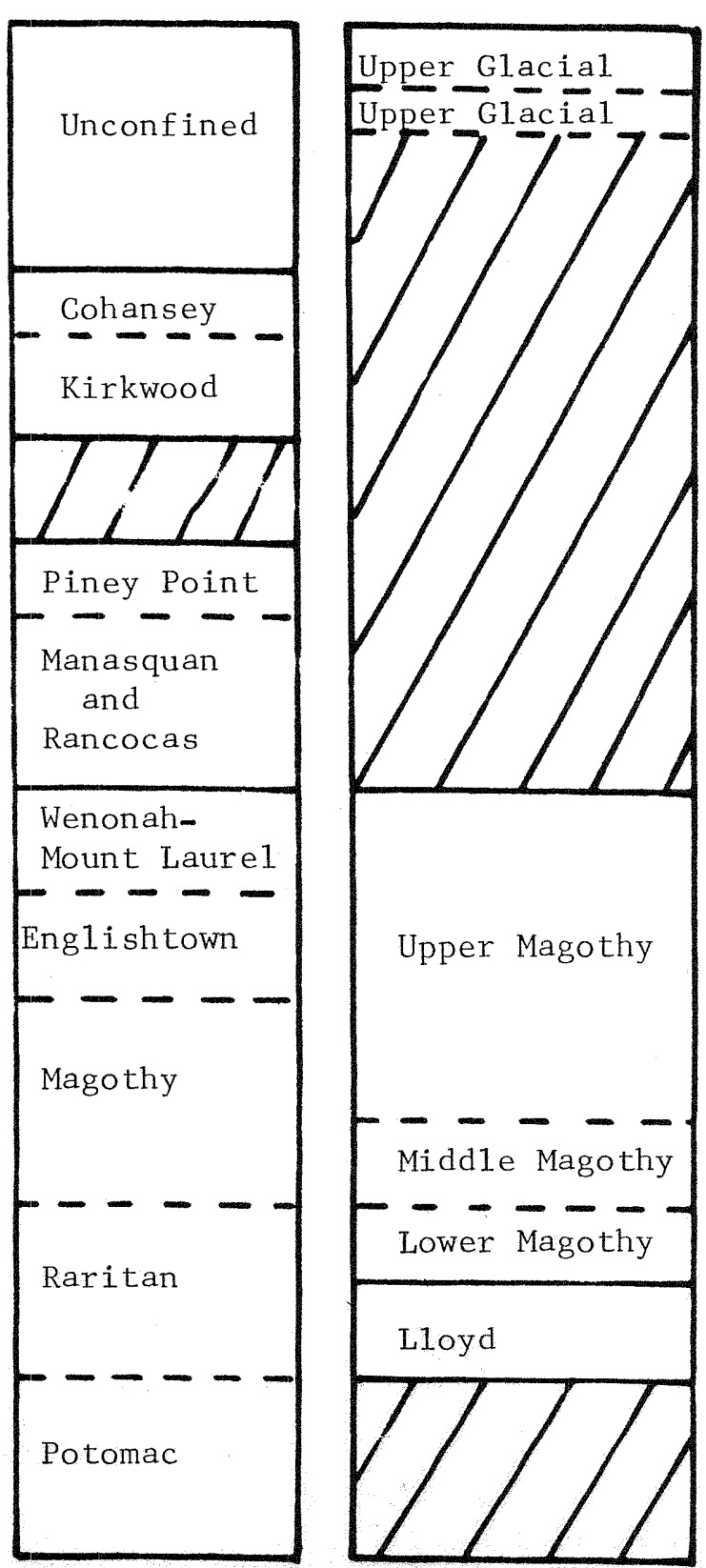

Figure 6.--Preliminary designation of aquifers for district work plans. 
Available hydrologic and geologic data will be entered into a central system and stored on discs compatible with the Maryland and Delaware District's computer system. Additional data needs will be met through data-collection programs that include an observation-well network, a base-flow program to determine ground-water recharge and discharge, test drilling, and geophysical logging. Water-quality data will be evaluated and additional samples collected; emphasis will be placed on evaluation of saline ground water.

Three types of computer simulation modeling will be undertaken. A coarse-grid model of the Coastal Plain in Maryland and Delaware will simulate the eight principal and two minor aquifers by ten model layers and employ about 2,000 nodes per model layer. This model will provide boundary conditions for fine-grid models in problem areas. Two proposed cross-sectional models to simulate steady-state conditions prior to ground water development will be made; (1) a section from Anne Arundel County to Ocean City, Maryland, and (2) a section from Harford County, Maryland, eastward across Delaware to the ocean.

Several reports will be prepared during the project. They include an open-file report, several U.S. Geological Survey Water Resources Investigation (WRI) map reports containing a series of hydrogeologic maps for each of the principal aquifers, a U.S. Geological Survey Professional Paper chapter on the results of the Maryland and Delaware subregional project, and journal articles on simulation modeling. 
The Coastal Plain aquifer system underlies about 4,000 square miles in New Jersey. Coastal Plain sediments composed of clay, silt, sand, and gravel, range in age from cretaceous to Holocene, and overlie bedrock of Precambrian, early Paleozoic and Triassic age. Thickness of the Coastal Plain sediments ranges from a featheredge along the western boundary of the Coastal Plain to about 6,500 feet at the southern tip of New Jersey. Principal aquifers (see figure 6) of the New Jersey Coastal Plain, from youngest to oldest, are: the Cohansey Sand of Miocene age, the Kirkwood Formation of Miocene age, the Wenonah-Mount Laurel aquifer of Late Cretaceous age, the Englishtown aquifer of Late Cretaceous age, and the Potomac-Raritan-Magothy aquifer system of Early to Late Cretaceous age.

Withdrawal from the principal aquifers and several minor aquifers in the New Jersey Coastal Plain is about $400 \mathrm{Mgal} / \mathrm{d}$. About $250 \mathrm{Mgal} / \mathrm{d}$ is withdrawn from the Potomac-RaritanMagothy aquifer system, $120 \mathrm{Mgal} / \mathrm{d}$ from the Cohansey and Kirkwood aquifers, $15 \mathrm{Mgal} / \mathrm{d}$ from the Englishtown and Wenonah-Mount Laurel aquifers, and $15 \mathrm{Mgal} / \mathrm{d}$ from minor aquifers of Quaternary age.

Withdrawals have caused large cones of depression in the artesian heads of several aquifers. The deepest parts of the Potomac-Raritan-Magothy cone of depression occur in Camden and Middlesex Counties; however, widespread diversions from this aquifer have caused water-level declines throughout most of the New Jersey Coastal Plain. The cones of depression in the Englishtown and Wenonah-Mount Laurel aquifers are centered largely in Monmouth County in east-central New Jersey whereas the cone of depression in the Kirkwood aquifer is largely along the southern coast of New Jersey in Atlantic and Cape May Counties.

Other problems in the New Jersey Coastal Plain are saltwater intrusion, which has been noted in Monmouth County and in Cape May County at the southern tip of New Jersey, and ground-water pollution resulting from industrial and municipal waste disposal.

The program of ground-water investigations in New Jersey has been carried out largely in cooperation with the New Jersey Department of Environmental Protection (NJDEP), Division of Water Resources. Most aspects of this program relate directly to the subregional project as knowledge of the hydrogeology, ground-water withdrawals, water levels, and of saltwater intrusion result from this program. Computer simulation models of several of the principal aquifers have been developed under the cooperative program and development 
of a model of the Cohansey Sand aquifer in cooperation with both NJDEP and the U.S. Army Corps of Engineers is in progress. Development of a multi-layer steady-state model of the entire New Jersey Coastal Plain was started in cooperation with the NJDEP. Studies of water quality in the Potomac-Raritan-Magothy aquifer system and of subsidence are scheduled to start or are in progress.

Geologic, hydrologic, and geochemical data will be compiled and a computerized data file for automatic storage and retrieval will be developed. Hydrogeologic and geochemical maps will be developed and provided to the regional study team. New data, including water-quality samples, will be collected. Sensitivity analysis and inverse techniques applied to computer simulation modeling will be used to evaluate unknown or poorly known aquifer properties.

Two computer simulation models are planned. The first, a steady-state model of the entire New Jersey Coastal Plain started in cooperation with the NJDEP, will simulate the five principal and three minor aquifers by ten model layers and will employ between 1,000 and 3,000 nodes per model layer. The second model will be a transient model similar in size and number of nodes to the steady-state model, although a coarser grid spacing may be necessary because of the added complexity of simulating transient leakage from confining units.

Results of this investigation will be presented in three reports: (1) a U.S. Geological Survey Water Resources Investigation (WRI) report presenting the steady-state model and the hydrogeologic maps used to develop the model; (2) a U.S. Geological Survey Professional Paper chapter on the transient model of, the New Jersey Coastal Plain; and (3) a U.S. Geological Survey WRI on the detailed transient model of the Potomac-Raritan-Magothy aquifer system. 


\section{New York}

The Atlantic Coastal Plain of New York occurs primarily on Long Island, an area of approximately 1,400 square miles. Coastal Plain sedimments are primarily of Pleistocene and Cretaceous age. They dip to the south and southeast and attain a maximum thickness of about 2,000 feet along the south central shore. The three principal aquifers (see figure 6), from youngest to oldest, are the Upper Glacial aquifer of Pleistocene age, the Magothy aquifer of Late Cretaceous age, and the Lloyd aquifer of Late Cretaceous age.

Groundwater pumpage is about $500 \mathrm{Mgal} / \mathrm{d}$ distributed as follows: $110 \mathrm{Mgal} / \mathrm{d}$ from the Upper Glacial aquifer, 365 Mgal/d from the Magothy aquifer, and $25 \mathrm{Mgal} / \mathrm{d}$ from the Lloyd aquifer. Pumpage locally exceeds recharge in central Queens County and southwestern Nassau County where extensive cones of depression exist and the freshwater supply is threatened by saltwater intrusion.

Groundwater investigations in Long Island have been carried out in cooperation with the Nassau County Department of Public Works, Suffolk County Water Authority, and Suffolk County Department of Health Services. These investigations resulted in development of both a five-layer computer simulation model and a five-layer electric analog model of the Long Island aquifer system.

The computer simulation model will be modified for this project as follows: (1) a two-dimensional model of the Lloyd aquifer will be developed; this model will have 2,000 nodes and a 6,000 foot grid spacing; (2) the Lloyd aquifer will be added to the five-layer model resulting in a six layer, 12,000 node model; (3) a finer-grid six-layer model having a 3,000 foot grid spacing will be developed for western Long Island (Kings and Queens Counties). A significant aspect of the western Long Island modeling effort will be a study of the relation of the hydrogeology of western Long Island to that of Monmouth and Middlesex Counties, New Jersey.

Four reports are planned for this study: a U.S. Geological Survey Water Resources Investigation (WRI) report documenting each of the three developed models and a U.S. Geological Survey Professional Paper chapter describing the entire study of the Long Island aquifer system. 
North Carolina

The Coastal Plain aquifer system underlies about 25,000 square miles in North Carolina and is the major source of freshwater in the North Carolina Coastal Plain. Coastal Plain sediments ranging in age from Cretaceous to Holocene, thicken eastward from a featheredge at the western limit of the Coastal Plain to about 10,000 feet at Cape Hatteras. Six hydrogeologic units (see figure 6) have been identified in the Coastal Plain. From youngest to oldest, these are a surficial hydrogeologic unit of post-Miocene age, the Yorktown hydrogeologic unit which includes sediments of Pliocene and Miocene age, the Castle Hayne hydrogeologic unit composed of limestone of Eocene and Oligocene age, the Beaufort hydrogeologic unit of Paleocene age, the PeedeeBlack Creek hydrogeologic unit of Late Cretaceous age, the Tuscaloosa hydrogeologic unit which includes the cape Fear Formation of Late Cretaceous age, and unnamed beds of Early to Late Cretaceous age.

Withdrawal from these units for municipal and industrial use (including phosphate-mine dewatering) and some irrigation is estimated at $155 \mathrm{Mgal} / \mathrm{d}$. About $95 \mathrm{Mgal} / \mathrm{d}$ is withdrawn from the Castle Hayne unit, most of it from phosphate mine dewatering in Beaufort County, and about $60 \mathrm{Mgal} / \mathrm{d}$ from the units of Cretaceous age. Many years of ground-water withdrawal have resulted in extensive cones of depression in the Castle Hayne unit in Beaufort and surrounding counties and in hydrogeologic units of cretaceous age in Halifax, Lenoir, and Craven Counties. Pumping in the vicinity of Franklin, Virginia has created a large cone of depression that extends into North Carolina, influencing water levels in the 1600 square miile area north of Albermarle sound. Saltwater has moved into previously freshwater parts of the Castle Hayne unit in response to dewatering in Beaufort county.

The North Carolina Department of Natural Resources and Community Development (DNRCD) is conducting a program of data collection that includes test drilling, geologic and geophysical logging, aquifer testing, and observation wells in order to define the stratrigraphy and hydrogeology of the Coastal Plain. Detailed studies by DNRCD in selected areas in Beaufort, Lenoir, and Craven Counties include water-use data collection, aquifer tests, and analysis of streamflow. The North Carolina District and DNRCD are cooperating in the National Water Use Data Study and in a comprehensive observation well network.

The North Carolina District will collect and compile geologic, hydrologic, and geochemical data. Major sources of these data are in the files of the U.S. Geological Survey and 
North Carolina water agencies. Pumpage data will be obtained largely through a concurrent water use data study. Maps of hydrogeologic and geochemical parameters will be compiled for each of six hydrogeologic units. Collection of new data to fill information gaps will be coordinated with the DNRCD program.

Steady-state and transient computer models simulating the six hydrogeologic units by about eight model layers will be developed to analyze the North Carolina Coastal Plain aquifer system. The models will employ about 3,000 nodes per model layer and have a grid spacing of about 3 miles on a side. Closer grid spacing may be used in some areas of large ground-water withdrawal such as in Beaufort, Halifax, Lenoir, and Craven Counties.

Three reports are planned: a U.S. Geological Survey Water Resources Investigation (WRI) report containing hydrogeologic data; a U.S. Geological Survey Professional Paper chapter on the North Carolina computer simulation models; and a WRI report on the effects and management of large withdrawals from the Cretaceous aquifer in Lenoir and Craven Counties.

\section{Virginia}

The Atlantic Coastal Plain of Virginia is an area of about 13,000 square miles underlain by deposits of sand, silt, and clay ranging in age from cretaceous or older to Quaternary. The sediments dip to the southeast at 10 to 50 feet per mile and thicken southeastward from a featheredge at the western limit of the Coastal Plain to about 6,500 feet on the Delmarva Peninsula. Four principal aquifers (see figure 6) have been identified in Virginia. These are, from youngest to oldest: the Quaternary aquifer, the Chesapeake aquifer of Miocene and Pliocene age, the aquifer of Late Cretaceous age sediments, and the aquifer of undifferentiated Cretaceous sediments.

Withdrawal from these units is estimated at $145 \mathrm{Mgal} / \mathrm{d}$ but almost all of it, $140 \mathrm{Mgal} / \mathrm{d}$, is from the undifferentiated Cretaceous aquifer. Pumpage from four communities, Franklin, Williamsburg, Suffolk, and West Point, accounts for $80 \mathrm{Mgal} / \mathrm{d}$ from this aquifer. 
The long-term utility of the aquifer of undifferentiated Cretaceous sediments is being threatened by declining water levels and by the occurrence of saltwater in coastal areas. Concentrated ground-water withdrawals at Franklin, Suffolk, Williamsburg, and West Point in southeastern Virginia have caused the expansion and coalescence of several cones of depression that extend into northeastern North Carolina. Reduction in hydraulic head in clay confining beds has resulted in land subsidence in the Franklin area. The State of Virginia has identified southeastern Virginia and the Eastern Shore as areas of potentially critical water shortages.

Geologic, hydrologic, and geochemical data will be compiled and analyzed and will form the basis of hydrogeologic and geochemical maps. New data will be collected and analyzed to improve and refine the maps, particularly in areas of major data deficiencies such as the Northern Neck Peninsula in east-central Virginia.

Steady-state and transient computer simulation models will be developed for the Virginia Coastal Plain and will extend southward to Albemarle Sound in North Carolina. The models will probably simulate the four principal and two minor aquifers by about eight model layers and have 2,000 to 4,000 nodes per model layer. Variable grid spacing will be used; the finer grids covering areas of significant hydrologic stress.

Findings of the study will be presented in a U.S. Geological Survey Professional Paper chapter at the conclusion of the study. Preliminary findings, published as open-file reports, U.S. Geological survey Water Resources Investigations (WRI), and journal articles, will contain data compilations, hydrogeologic maps, and cover special topics such as computer simulation modeling and occurrence of saline ground water. 
Brown, P. M., 1959, Geology and ground-water resources in the Greenville area, North Carolina: North Carolina

Department of Conservation and Development Bulletin no. $73,87 \mathrm{p}$.

Brown, P. M., Miller, J. A., and Swain, F. M., 1972, Structural and stratigraphic framework, and spatial distribution of permeability of the Atlantic Coastal Plain, North Carolina to New York: U.S. Geological Survey Professional Paper 796, 79 p.

Cushing, E. M., Kantrowitz, I. H., and Taylor, K. P., 1973, Water resources of the Delmarva Peninsula: U.S. Geological Survey Professional Paper 822, 58 p.

Farlekas, G. M., Nemickas, Bronius, and Gill, H. E., 1976, Geology and ground-water resources of Camden County, New Jersey: U.S. Geological Survey Water-Resources Investigations $76-76,146 \mathrm{p}$.

Franke, O. I., and McClymonds, N. E., 1972, Summary of the hydrologic situation on Long Island, New York, as a guide to water-management alternatives: U.S. Geological Survey Professional Paper 627-F, $59 \mathrm{p}$.

Hathaway, J. C., 1976, Preliminary summary of the 1976 Atlantic Margin coring project of the U.S. Geological Survey: U.S. Geological Survey Open-file report 76-844, $217 \mathrm{p}$.

Perry, W. J., Jr., Minard, J. P., Weed, E. G. A., Robbins, E. I., and Rhodehamel, E. C., 1975, Stratigraphy of Atlantic Coastal Margin of United States north of Cape Hatteras - brief survey: American Association of Petroleum Geologists Bulletin, v. 59, no. 9, p. 1529-1548.

Sumsion, C. T., 1970, Geology and ground-water resources of Pitt County, North Carolina: North Carolina Department of Water and Air Resources Ground Water Bulletin no. 18, $75 \mathrm{p}$.

Ward, L. W., Lawrence, D. R., and Blackwelder, B. W., 1978, Stratigraphic revision of the Middle Eocene, Oligocene, and Lower Miocene - Atlantic Coastal Plain of North Carolina: U.S. Geological Survey Bulletin 1457-F, 23 p. 